\title{
回転磁束条件下のベクトル磁気ヒステリシスの検討
}

\section{Vector Magnetic Hysteresis Characteristics under Rotational Magnetic Flux Conditions}

\author{
榎園 正人 ${ }^{* 1}$ (正員)，若林 大輔*2(正員)，甲斐 祐一郎*3(正員)
}

Masato ENOKIZONO (Mem.), Daisuke WAKABAYASHI(Mem.), Yuichiro KAI(Mem.)

\begin{abstract}
This paper presents measured results of the two-dimensional vector magnetic properties in the electrical steel sheets under rotational flux conditions. In the vector magnetic characteristics under rotating magnetic flux conditions, the ratio of alternating hysteresis and rotating hysteresis differs depending on the change in the axial ratio under rotating magnetic flux conditions. This axis rate change from vector magnetic hysteresis loop characteristics are analyzed and clarified details.
\end{abstract}

Keywords: vector magnetic property, spatial difference phase angle, rotational magnetic flux, rotational core loss, vector locus, axis ratio, electrical steel sheet.

(2019 年 9 月 25 日受付, 2021 年 6 月 2 日再受付)

\section{1 緒言}

ベクトル磁気特性は，任意方向並びに回転磁束条件 下の磁気特性を示すもので，電磁場解析や磁性材料の 電磁力機器への有効活用技術を示唆するものとして生 まれた。従来の磁性材料の磁気特性評価法は, JIS や IEC 規格に基づく標準測定法が一般的である。しかし ながらそれは前述の諸条件による特性を表していない。 他方，磁性材料の磁気特性における磁気損失（鉄損） の中のヒステリシス損失に着目すると, その発生原因 は, 磁壁移動, 磁化回転並びに磁壁の発生・消滅課程 に基づく $[1,2]$ 。そしてこの現象はヒステリシス特性と して示すことができる。しかしながら従来のヒステリ シス特性は前述の諸条件に対応したものになっていな い。従来のヒステリシス表現は，電力機器の低損失・ 高効率化に加えて高パワー密度化が求められている中 で，電気機器鉄心中の磁気特性を従来の解析法で詳細 な吟味を行うことを妨げている。もし，鉄心中の磁気 的挙動を正確に把握することができれば，それは高性 能化に向けた機器設計の改変につながり，損失の低減 化の方針を示唆できることになる $[3]$ 。

他方, 電圧 ・電流・力率から構成される電気特性と 磁気特性の関連性の検討もいまだ不十分である。この

\footnotetext{
連絡先： 榎園 正人, $\overline{\bar{T}} 879-0442$ 大分県宇佐市城井 533 番地, ベクトル 磁気特性技術研究所, e-mail: enoki@oita-u.ac.jp *1 ベクトル磁気特性技術研究所 ${ }^{* 2}$ 日本文理大学 *3 鹿児島大学
}

ことが電気機器を駆動するための外部回路の構成にと って不可欠な事項である。

本論文では従来のヒステリシス特性を見直し, 再構 成してベクトルヒステリシス特性を示し，それによっ て得られる特徽を明らかにする。

\section{2 回転磁束下の磁気特性}

実際の電気機器鉄心上で発生している磁気特性を, 三相 2 極の誘導モータ鉄心モデルにより調べた測定結 果を Fig. 1 に示した。

この測定は特殊なべクトル磁気特性測定用 V-Hセン サ $(5 \mathrm{~mm} \times 5 \mathrm{~mm})$ によって, 三相正弦波電圧下のモータ 鉄心内の磁束密度 $\mathbf{B}$ ベクトル並びに磁界強度 $\mathbf{H}$ ベク トルの挙動と一周期のリサージュ (ベクトル軌跡)を 測定した結果である。Fig. 2 はモー夕鉄心の代表的な 固定子ヨーク部とティース部付近の各ベクトル軌跡を 表している。この測定結果が示すように，モータ鉄心



Fig. 1 Behavior of vector $\mathbf{B}$ and vector $\mathbf{H}$ in the model motor core. 




Fig. 2 Rotational magnetic characteristics in motor core.

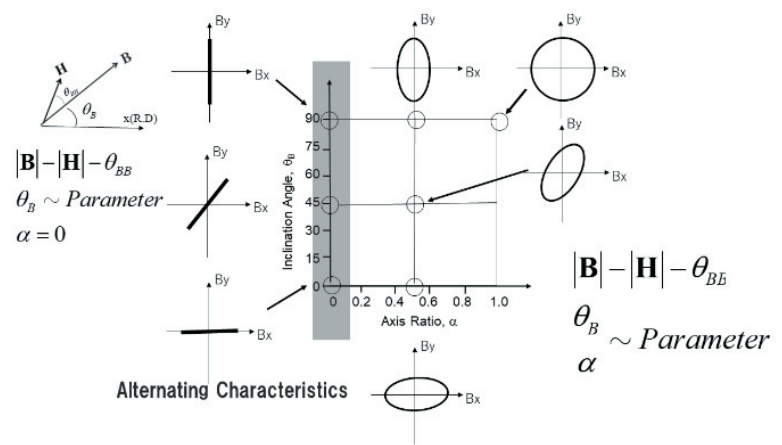

Fig. 3 Definition of vector measurement conditions.

内のあらゆる箇所で向きの異なる楕円形の回転磁束並 びに回転磁界を形成している。これは三相電圧駆動に よって回転磁界が生成されることによる。このような 回転磁束下の磁気特性は，通常の磁気特性測定で表す ことができない。

この回転磁束下のベクトル磁気特性は, 磁束密度べ クトルの軌跡で表す軸比 $\alpha$ を使って, Fig. 3 のように 各条件を定義できる。 $\alpha=0$ は交番磁束条件を表すが全 体を回転磁束条件下で取りまとめることができる。以 上の結果から回転磁束下のべクトル磁気特性として $|\mathbf{B}|,|\mathbf{H}|$, ベクトル $\mathbf{B}$ 並びに楕円磁束の長軸の傾き角 $\theta_{\mathrm{B}}$, $\alpha$ そしてベクトル $\mathbf{B}$ とベクトル $\mathbf{H}$ の間の空間的位相 差角 $\theta_{\mathrm{BH}}\left(=\theta_{\mathrm{H}}-\theta_{\mathrm{B}}\right)$ で表すことができる。

\section{3 ベクトル磁気ヒステリシスループ特性}

ベクトル磁気特性は $\theta_{\mathrm{BH}}-|\mathbf{B}|,-|\mathbf{H}|$ の特性として $\theta_{\mathrm{B}}$ 及 び $\alpha$ 毎に三次元的な特性表示で表すことができ，これ をベクトル磁気ヒステリシスループと呼ぶことにし， $|\mathbf{B}|-|\mathbf{H}|$ の大きさのみについての関係を磁気スカラーヒ ステリシスループとした。なお，ベクトル量の大きさ を波形の視点でとらえるため士 $|\mathbf{H}|$ および士 $|\mathbf{B}|$ の形 をとることにする。

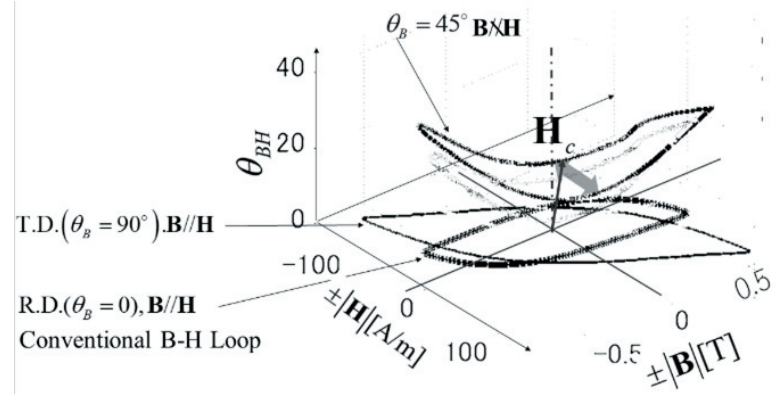

Fig. 4 Vector magnetic hysteresis loop characteristics under alternating flux condition of non-oriented electrical steel sheet.



Fig. 5 Definition of rotational flux condition.

Fig. 4 は $\alpha=0$ （交番磁束条件下に相当）の場合，無 方向性電磁鋼板について $\theta_{\mathrm{B}}$ をパラメータとする任意 方向のベクトル磁気ヒステリシスループ特性を示す。

圧延方向 $\theta_{\mathrm{B}}=0^{\circ}$ 並びに圧延方向に直角方向 $\theta_{\mathrm{B}}=$ $90^{\circ}$ の時， $\mathbf{B}$ ベクトルと $\mathbf{H}$ ベクトルは平行になり，空 間的位相差角 $\theta_{\mathrm{BH}}=0^{\circ}$ となる。 $\mathbf{B}$ ベクトルの圧延方向 からの傾き角 $\theta_{\mathrm{B}}$ が傾いた任意方向のベクトル磁気ヒ ステリシスループは, 湾曲した形状となりヒステリシ スループの面積が増大し磁気損が増加することを示す。 このように磁気損失の特性に $\theta_{\mathrm{BH}}$ の関与は大きく, 従 来の特性評価からこの磁気損失の増加を説明すること は難しい。以上のことから $\theta_{\mathrm{BH}}$ の特性に着目したベク トル磁気ヒステリシスループを分析することにより, 交番磁束と回転磁束が混在した回転ヒステリシス磁気 特性を分析することができ，全体を回転磁束下の磁気 特性として統一的に捉えることができるはずである。

\section{4 回転磁束下のベクトル磁気ヒステリシス特性}

Fig. 5 は回転磁束下の $\mathbf{B}$ ベクトル並びに $\mathbf{H}$ ベクトル の各々が作るベクトル軌跡でベクトル $\mathbf{B}$ の軌跡が作る 長軸 $\mathrm{a}$ の大きさを $\mathbf{B}_{\mathrm{m}}$ とする基軸に，条件設定するた

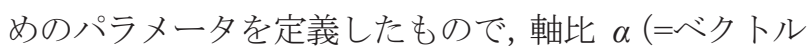
B の軌跡から短軸と長軸の長さの比: =b/a）を用いて, $\alpha=0$ の交番磁束下の特性を含む連続した条件下で表 すことができる $[3,4]$ 。 


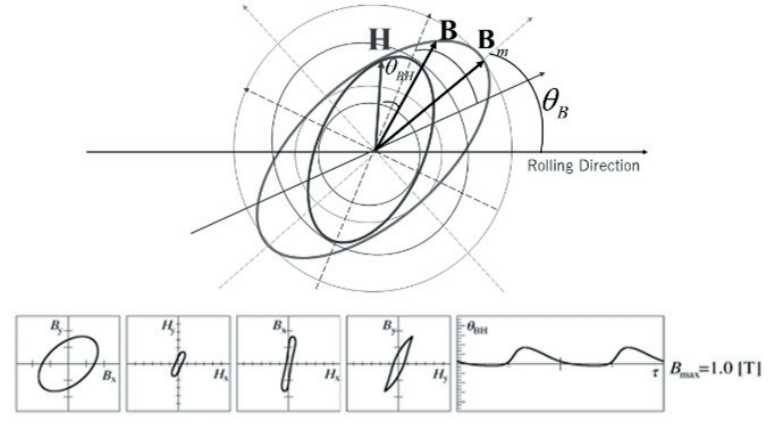

Fig. 6 Locus of vector $\mathbf{B}$ and vector $\mathbf{H}$ under rotational flux condition.


Fig. 7 Vector magnetic characteristics under rotational flux condition of non-oriented steel sheet, $B_{m}=1.0[\mathrm{~T}], \theta_{B}=0^{\circ}, \alpha=0-0.8$.

Fig. 6 は棈円回転磁束下 $\left(\theta_{\mathrm{B}}=45^{\circ}, \alpha=0.6\right)$ の $\mathbf{B}$ ベ クトル並びに $\mathbf{H}$ ベクトルの各々が作るベクトル軌跡 と $\mathrm{x}$ 並びに $\mathrm{y}$ 方向に分解したヒステリシスループと $\theta_{\mathrm{BH}}$ の変化を示す。このように磁気特性は $|\mathbf{B}|$ と|$|\mathbf{H}|$ の関 係のみならず $\theta_{\mathrm{BH}}$ においても非線形ヒステリシスを示 している

\section{1 無方向性電磁鋼板の回転磁束ベクトル磁気ヒステ リシスループ特性}

Fig. 7 は無方向性電磁鋼板について, 長軸方向の B= $1.0 \mathrm{~T}$ における $\theta_{\mathrm{B}}=0^{\circ}$ の条件下でベクトル磁気特性測 定から得られた $\mathbf{B}$ ベクトル軌跡, $\mathbf{H}$ ベクトル軌跡, $\mathrm{B}_{\mathrm{x}}$ - $\mathrm{H}_{\mathrm{x}}$ 及び $\mathrm{B}_{\mathrm{y}}-\mathrm{H}_{\mathrm{y}}$ ヒステリシスループを軸比 $\alpha=0 \sim 0.8$ に 変化させた場合について示す。

Fig. 8 は $\theta_{\mathrm{BH}}$ - $|\mathbf{H}|-|\mathbf{B}|$ ベクトル磁気ヒステリシスルー プとして表した。この結果が示すように， $\alpha$ の増大に 伴ないヒステリシスループの形が湾曲して行くと, 共 に|B|のバイアスがかかりヒステリシスループの中心 が右側にシフトしている。このループ形状の変化とシ フトする特性が回転磁束下の特徵として捉えることが できる。さらに，この $\alpha$ の増大によって回転磁束成分 の増大に伴う特性の変化を分析するため, Fig. 9 に示 す(a)ベクトルの大きさに着目した $|\mathbf{B}|-|\mathbf{H}|$ ヒステリシ

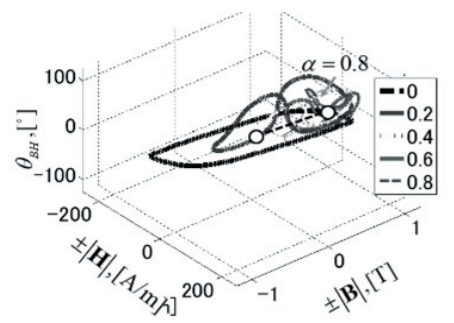

Fig. $8 \quad \theta_{\mathrm{BH}}-|\mathbf{H}|-|\mathbf{B}|$ vector hysteresis loop of nonoriented steel sheet.



(a) $|\mathbf{B}|-|\mathbf{H}|$ hysteresis loop.



(b) $\theta_{\mathrm{BH}}-|\mathbf{B}|$ hysteresis loop.
Fig. 9 Comparison between $|\mathbf{B}|-|\mathbf{H}|$ scalar hysteresis loop and $\theta_{\mathrm{BH}}-|\mathbf{B}|$ butterfly hysteresis loop,

$$
|\mathbf{B}|_{m}=1.0[\mathrm{~T}], \theta_{B}=0^{\circ}, \alpha=0-0.8 \text {. }
$$

ス特性と(b)位相差角 $\theta_{\mathrm{BH}}-|\mathbf{B}|$ 必須テリシス特性につい て個別の分析を行う。

Fig. 9 から $|\mathbf{B}|-|\mathbf{H}|$ 特性と $\theta_{\mathrm{BH}}$ - $|\mathbf{B}|$ 特性を対比してみる と, 回転磁束の $\alpha$ の増加によって $\theta_{\mathrm{BH}}-|\mathbf{B}|$ 特性はバタフ ライループ特性を示しており，このヒステリシス特性 は $\alpha$ が小さいときは大きいがその後小さくなり,“○” で示した中心点が $+|\mathbf{B}|$ 側に移動している。これは回転 磁束成分の増加により $\theta_{\mathrm{BH}}$ がバイアス量に加えて変化 していることから, 磁化回転の発生による変化が増大 していることを示唆する。

以上の結果から, Fig. 10 はこの $|\mathbf{B}|$ に対する $|\mathbf{H}|$ の変化 から構成されるスカラー磁気ヒステリシスループとし て大きさの変化の様子を任意方向の傾き角 $\theta_{\mathrm{B}}$ と $\alpha$ を変 えて分析する。スカラー磁気ヒステリシス特性は $\mathrm{B}_{\mathrm{x}}$ $\mathrm{H}_{\mathrm{x}}$ 及び $\mathrm{B}_{\mathrm{y}}-\mathrm{H}_{\mathrm{y}}$ の分割されたヒステリシス特性と異な つている。Fig. 7 で示した二方向に分離したヒステリ シスループは，二次元励磁の入力一出力関係から構成 されたものであるため回転磁束条件下の特徴が捉えに くい。 $\alpha$ の増大とともにスカラヒステリシスループの 大きさは小さくなり，上部に移動していく。その移動 量を $\Delta|\mathbf{B}|$ と $\Delta|\mathbf{H}|$ を用いて表すと， $\Delta|\mathbf{H}|$ は+ $|\mathbf{H}|$ 側にシ フトし， $\Delta|\mathbf{B}|$ も $+|\mathbf{B}|$ 側にシフトし，その量は $\Delta|\mathbf{B}|=\alpha$ 


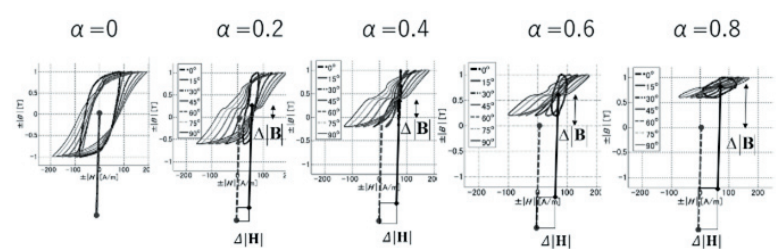

Fig. $10 \quad$ Effect of $\alpha$ on $|\mathbf{B}|-|\mathbf{H}|$ scalar hysteresis loop of non-oriented electrical steel sheet,

$|\mathbf{B}|_{m}=1.0[\mathrm{~T}], \theta_{B}=0^{\circ}-90^{\circ}, \alpha=0-0.8$.

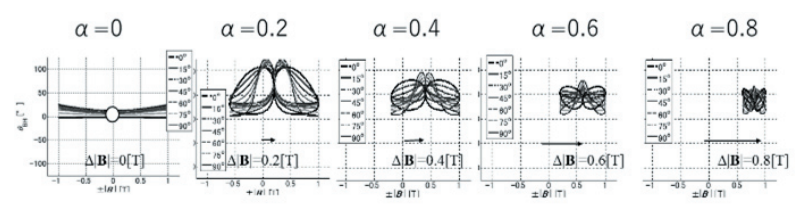

Fig. 11 Effect of $\alpha$ on $\theta_{\mathrm{BH}}|\mathbf{B}|$ characteristics of nonoriented electrical steel sheet,

$|\mathbf{B}|_{m}=1.0[\mathrm{~T}], \theta_{B}=0^{\circ}-90^{\circ}, \alpha=0-0.8$.

$B_{\mathrm{m}}$ の関係で増大する。

以上のことからスカラヒステリシスループは磁化 回転に依存しない部分からなる損失成分と考えてよい だろう。 $\alpha$ が大きくなると磁化回転並びに磁壁の発生 消滅課程に起因する回転鉄損部分が増大寸る。そこで, $\theta_{\mathrm{BH}}$ 特性を Fig. 11 にてみると， $\alpha$ の小さいところで急 激に大きな変化を示した後, 徐々に小さくなっている。 しかしながら $\Delta|\mathbf{B}|=\alpha B_{\mathrm{m}}$ は大きくなり回転磁束成分が 増大すると, 磁壁の発生消滅過程による磁気損失の増 加が生じてくる。

\section{2 方向性電磁鋼板の回転磁束ベクトル磁気ヒステリ} シスループ特性

方向性電磁鋼板は無方向性電磁鋼板に比べて配向 性が強く, 磁区構造は $180^{\circ}$ 磁区が支配的で，その大き さも大きい。それゆえ, 圧延方向励磁では磁壁移動が 率先して起こり磁気損失が大幅に減少するが，圧延方 向から傾くと急激に損失が増大する。Fig. 12 は方向性 電磁鋼板の回転磁束下におけるベクトル軌跡と $\mathrm{x}$ 方向 並びにy方向に分けられたヒステリシスループを示す。 無方向性電磁鋼板の傾向と全く異なる。このように, 方向性電磁鋼板の特性は特異で, 強い磁気異方性が起 因となるベクトル磁気特性を表す。Fig. 13 は方向性電 磁鋼板の $\theta_{\mathrm{BH}}-|\mathbf{H}|-|\mathbf{B}|$ ベクトル磁気ヒステリシスル 一プの $\alpha$ の増大による変化を示す。無方向性電磁鋼板 と大きく異なる点は $\theta_{\mathrm{BH}}$ が正負に幅広くまたがって変 化し, 湾曲の度合いも著しく大きくなっていることで



Fig. 12 Vector magnetic characteristics under rotational flux conditions of grain-oriented electrical steel sheet, $B_{m}=1.0[\mathrm{~T}], \theta_{B}=0^{\circ}, \alpha=0-0.8$.

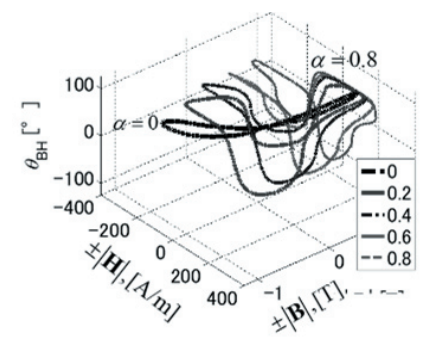

Fig. $13 \quad \theta_{\mathrm{BH}-}|\mathbf{H}|-|\mathbf{B}|$ vector hysteresis loop of grainoriented electrical steel sheet.

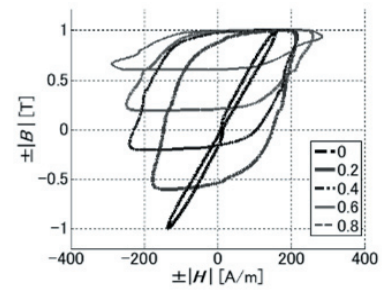

(a) $|\mathbf{B}|-|\mathbf{H}|$ hysteresis loop.

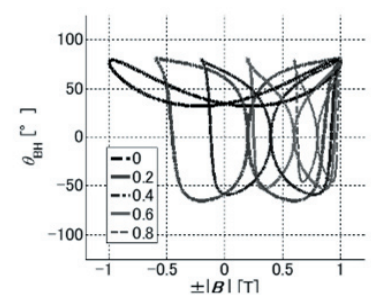

(b) $\theta_{\mathrm{BH}}-\mathbf{B} \mid$ hysteresis loop.
Fig. 14 Comparison between $|\mathbf{B}|-|\mathbf{H}|$ scalar hysteresis loop and $\theta_{\mathrm{BH}^{-}}|\mathbf{B}|$ butterfly hysteresis loop of grain-oriented electrical steel sheet.

ある。さらに詳細に検討するため, Fig. 14 に示すよう にスカラヒステリシスループ $|\mathbf{B}|-|\mathbf{H}|$ と位相差角 $\theta_{\mathrm{BH}}$ のバタフライループを見てみる。ヒステリシスループ の $\mathbf{H}$ 幅は $\alpha$ の増大によって大きくなっている。ヒステ リシスループの面積も大きく増大している。そしてヒ ステリシスループの中心点は $\alpha$ の変化に対してその変 化は鈍い。他方 $\theta_{\mathrm{BH}}$ のバタフライループは正負側に大 きく振れ中心点は+ $|\mathbf{B}|$ 側に移動していく。

以上のような方向性電磁鋼板の特異な現象を，分析 するため Fig. 15 に $\alpha=1$ の真円を形作る回転磁束下の $\theta_{\mathrm{BH}}$ の時間変化を示す。無方向性電磁鋼板の場合, 反時 計回り方向に H ベクトルが先行して回転し， Bベクト ルがそれに追随して回転する。ところが方向性電磁鋼 


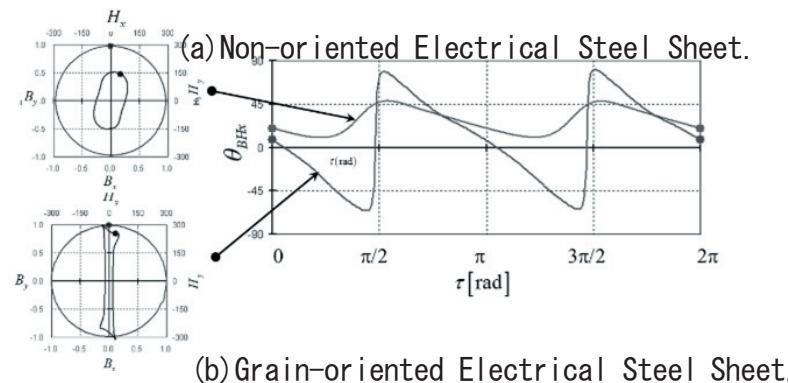

Fig. 15 Vrctor Locus and $\theta_{\mathrm{BH}}$ characteristics under circular rotational flux condition $(\mathrm{a}=1)$.



Fig. 16 Scalar hysteresis loop and vector hysteresis loop.

板の場合, 磁化軸容易方向に近づくと $\mathbf{B}$ ベクトルの回 転速度が急激に増し， $\mathbf{H}$ ベクトルの回転を追い越して いる。その結果 $\theta_{\mathrm{BH}}$ は正負の領域にまたがって急速に 変化している。これは方向性電磁鋼板の固有の圧延方 向の高い磁化容易性に起因するものである。電磁鋼板 における異方性問題に関わる磁気現象は， $\theta_{\mathrm{BH}}$ の検討 を外して議論することは不可解さを残すことになって しまい, 磁気特性のモデリングや解析において, 注意 をする必要がある。また，方向性電磁鋼板の磁気特性 は, 直交異方性よりは一軸異方性に近い特性を持って いることが示唆される。

Fig. 16 は電磁鋼板の種類によるベクトル磁気ヒステ リシスループ特性と $|\mathbf{B}|-|\mathbf{H}|$ スカラー磁気ヒステリシス ループ特性並びに $\theta_{\mathrm{BH}}-|\mathbf{H}|$ 特性を示す。ここで比較の 際は|H|の違いが顕著に出ることから, 特性表示を $\mathrm{B}_{\mathrm{m}}=1 \mathrm{~T}$ 一定で示した。無方向性電磁鋼板間の種別によ る相違は相対的に小さいが，方向性電磁鋼板と無方向 性電磁鋼板の間には著しい特性の相違がみられる。こ のようにベクトル磁気ヒステリシス特性は，材料の特 徵を明瞭にすることができる。

\section{5 磁気損失特性}

回転磁束下の磁気特性は, 電磁鋼板の磁化過程によ って磁壁移動を主とする交番磁気損失と磁化回転並び

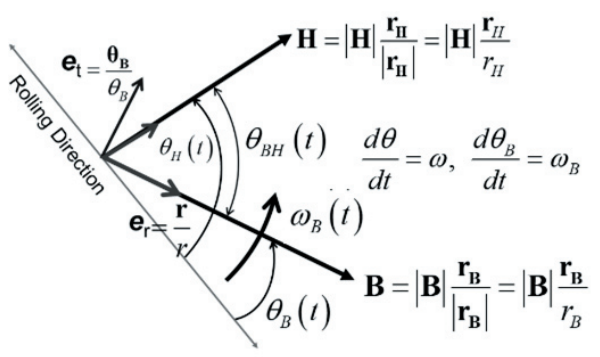

Fig. 17 Definition of vector behavior under rotational flux condition.

に磁壁の発生消滅現象による回転磁気損失に場の数式 から分析することが可能である。

Fig. 17 は, 回転磁束条件下の $\mathbf{B}$ 並びに $\mathbf{H}$ ベクトル を r - $\theta$ の極座標で定義したものである。ここで，各べ クトルの方向と大きさ図に定義し， $\mathbf{B}$ ベクトルの回転 角速度 $\omega_{\mathrm{B}}$ を導入する $[5,6]$ 。

それぞれのベクトル值を示すと以下のようになる。

$$
\mathbf{B}=\left|\mathbf{B}\left(t, \theta_{B}\right)\right| \frac{\mathbf{r}_{\mathbf{B}}}{\left|\mathbf{r}_{\mathbf{B}}\right|}=|\mathbf{B}| \frac{\mathbf{r}_{\mathbf{B}}}{\left|\mathbf{r}_{\mathbf{B}}\right|}
$$

$$
\begin{aligned}
& \mathbf{H}=\left|\mathbf{H}\left(t, \theta_{H}\right)\right| \frac{\mathbf{r}_{\mathbf{H}}}{\left|\mathbf{r}_{\mathbf{H}}\right|}=|\mathbf{H}| \frac{\mathbf{r}_{\mathbf{H}}}{\left|\mathbf{r}_{\mathbf{H}}\right|} \\
& \frac{\partial \mathbf{B}}{\partial t}=\frac{d\left|\mathbf{B}\left(t, \theta_{B}\right)\right|}{d t} \frac{\mathbf{r}_{\mathbf{B}}}{\left|\mathbf{r}_{\mathbf{B}}\right|}+\frac{\partial\left|\mathbf{B}\left(t, \theta_{B}\right)\right|}{\partial \theta} \frac{d \theta_{B}}{d t} \frac{\boldsymbol{\theta}_{B}}{\left|\boldsymbol{\theta}_{\mathbf{B}}\right|} \\
& =\frac{d\left|\mathbf{B}\left(t, \theta_{B}\right)\right|}{d t} \frac{\mathbf{r}_{B}}{\left|\mathbf{r}_{\mathbf{B}}\right|}+\omega_{B} \frac{\partial \mid \mathbf{B}\left(t, \theta_{B}\right)}{\partial \theta} \frac{\mid \boldsymbol{\theta}_{B}}{\left|\boldsymbol{\theta}_{\mathbf{B}}\right|} \\
& =\frac{d|\mathbf{B}|}{d t} \frac{\mathbf{r}_{B}}{\left|\mathbf{r}_{\mathbf{B}}\right|}+\omega_{B} \frac{\partial|\mathbf{B}|}{\partial \theta} \frac{\boldsymbol{\theta}_{B}}{\left|\boldsymbol{\theta}_{\mathbf{B}}\right|} \\
& W=\frac{1}{\rho T} \int_{0}^{T} \mathbf{H} \cdot \frac{\partial \mathbf{B}}{\partial t} d t=\frac{1}{\rho T} \int_{0}^{T}|\mathbf{H}| \frac{\mathbf{r}_{\mathbf{H}}}{\left|\mathbf{r}_{\mathbf{H}}\right|} \cdot\left(\frac{d|\mathbf{B}|}{d t} \frac{\mathbf{r}_{\mathbf{B}}}{\left|\mathbf{r}_{\mathbf{B}}\right|}+\omega_{B}|\mathbf{B}| \frac{\boldsymbol{\theta}_{B}}{\left|\boldsymbol{\theta}_{\mathbf{B}}\right|}\right) d t \\
& =\frac{1}{\rho T} \int_{0}^{T}|\mathbf{H}| \frac{d|\mathbf{B}|}{d t}\left(\frac{\mathbf{r}_{\mathbf{H}}}{\left|\mathbf{r}_{\mathbf{H}}\right|} \cdot \frac{\mathbf{r}_{\mathbf{B}}}{\left|\mathbf{r}_{\mathbf{B}}\right|}\right) d t+\frac{1}{\rho T} \int_{0}^{T} \omega_{B}|\mathbf{H}||\mathbf{B}|\left(\frac{\mathbf{r}_{\mathbf{H}}}{\left|\mathbf{r}_{\mathbf{H}}\right|} \cdot \frac{\boldsymbol{\theta}_{\mathbf{B}}}{\left|\boldsymbol{\theta}_{\mathbf{B}}\right|}\right) d t \\
& =\frac{1}{\rho T} \int_{0}^{T}|\mathbf{H}| \frac{d|\mathbf{B}|}{d t} \cos \theta_{B H} d t+\frac{1}{\rho T} \int_{0}^{T} \omega_{B}|\mathbf{H}||\mathbf{B}| \cos \left(\frac{\pi}{2}-\theta_{B H}\right) d t \\
& =\frac{1}{\rho T} \int_{0}^{T}|\mathbf{H}| \frac{d|\mathbf{B}|}{d t} \cos \theta_{B H} d t+\frac{1}{\rho T} \int_{0}^{T} \omega_{B}|\mathbf{H}||\mathbf{B}| \sin \theta_{B H} d t \\
& =W_{\text {alt }}+W_{\text {rot }}
\end{aligned}
$$


クトルで磁気損失は一周期の積分で表せる。 $W_{\text {alt }}$ は式 (4)の前項で交番磁気損失， $W_{\text {rot }}$ は後項で回転磁気損失 とみなせる。ポインティングベクトル式から得られた 磁気損失の式は，式(5)の関係にある。

$$
\begin{aligned}
W=\frac{1}{\rho T} \int_{0} \mathbf{H} \bullet \frac{\partial \mathbf{B}}{\partial t} d t & =\frac{f^{T}}{\rho} \int_{0}^{T}\left(H_{x} \frac{\partial B_{x}}{\partial t}+H_{y} \frac{\partial B_{y}}{\partial t}\right) d t \\
& =W_{x}+W_{y} \\
& =W_{\text {alt }}+W_{r o t}
\end{aligned}
$$

上式を使って，それぞれの磁気損失の関係を Fig. 18 に(a)無方向性電磁鋼板及び(b)方向性電磁鋼板につい 


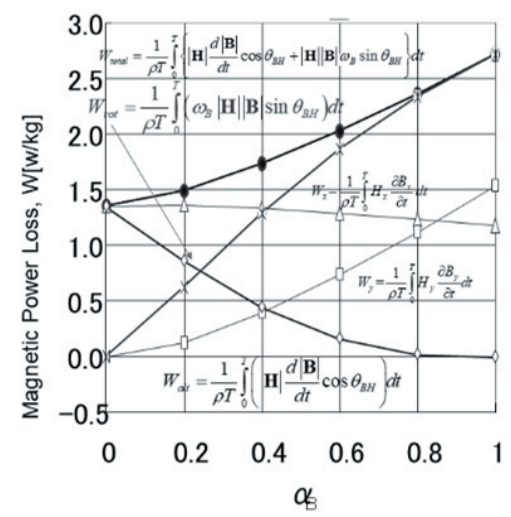

(a) Non-oriented electrical steel sheet.

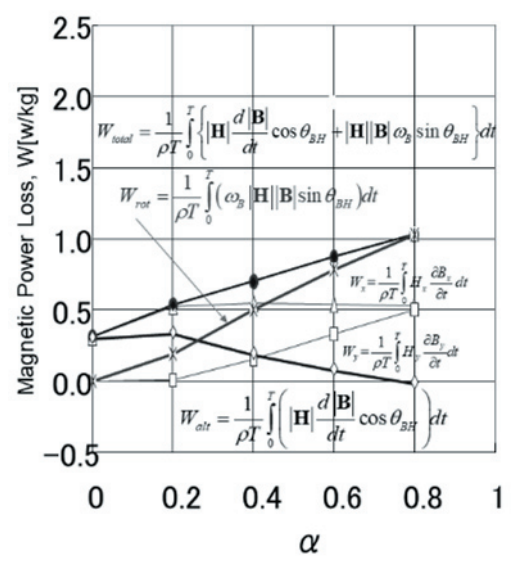

(b) Grain-oriented electrical steel sheet.

Fig. 18 Effect of axis ratio a on magnetic power loss.

て示す。磁気損失の測定は間接測定で磁束密度並びに 磁界強度用の探りコイルの出力から積分演算される。 磁気損失を数式に従って損失分離を試み，それぞれ の損失の挙動を知ることにより，電気機器の鉄心中の 各素質分布を把握でき損失抑制に向けた鉄心構造の設 計に寄与できる[7]。

\section{6 結言}

本論文において，交番磁束条件を回転磁束条件の一 つとして統一的にとらえ， $\mathbf{B}$ ベクトルと $\mathbf{H}$ ベクトルの 挙動に着目したベクトル磁気ヒステリシス特性を構築 して従来の磁気ヒステリシス特性の見直しを行った。 その結果以下の新しい知見が得られた。

1. $\mathbf{B}$ ベクトルと $\mathbf{H}$ ベクトルの間の空間的位相差角 $\theta_{\mathrm{BH}}$ が各ベクトルの大きさと強く相互に関係しあった ベクトル磁気ヒステリシスループを示した。

2. ベクトル磁気特性を回転磁束の視点から統一的に 見直し, 回転磁束によって回転磁束ベクトル磁気七
ステリシスループを示した。そして $|\mathbf{B}|-|\mathbf{H}|$ スカラー ヒステリシス特性や $\theta_{\mathrm{BH}}$ - $|\mathbf{B}|$ バタフライ特性を示し, 回転磁束の軸比 $\alpha$ に対するバイアス值 $\Delta \mathbf{B}, \Delta \mathbf{H}$ が 現れることを明らかにした。

3. 回転磁束の軸比や方向の変化によって $|\mathbf{H}|$ の大きさ より $\theta_{\mathrm{BH}}$ に及ぼす影響の方が大きく, 磁気特性の改 良や電気機器の鉄心形状設計に有用な手がかりと なる。

4. 磁気損失を交番磁気損失と回転磁気損失に分離が 可能で, ベクトル磁気ヒステリシス化により, 磁化 過程と対応した把握ができる。

今後は，このベクトル磁気ヒステリシスループの構成 要素と磁区を含めた磁化過程との関連を明らかにして いくことが望まれる。

\section{謝辞}

本研究は, JSPS 科研費基盤研究(A) (JSPS KAKENHI Grant Number JP17H01259) の助成を受けたものである。

\section{参考文献}

[1] J. D. Sievert, "Two-dimensional magnetic measurements history and achievements of the workshop", PRZEGLADD ELEKTROTECHNICZNY (Electrical Review), ISSN 00332097, R. 87 No 9b/2011, pp. 2-10, 2011.

[2] M. Enokizono, S. Kanao, J. Sievert, "Two-dimensional magnetic properties of silicon sheet subjected to a rotating field", IEEE Trans. Magn., vol. 29, pp. 3550-3552, Nov. 1993.

[3] M. Enokizono, "Two-dimensional (vector) magnetic property and improved magnetic field analysis for electrical machines", Journal of Materials Processing Technology, Vol. 108, Issue 2, pp. 225-231, 2001.

[4] W. Salz, K.A.Hempel, "Which field sensors are suitable for rotating flux apparatus? ", 1st Int. Workshop on Magnetic Properties of Electrical Sheet Steel under Two- Dimensional Excitation, Braunschweig (ed. J. Sievert), PTB-ReportPTB-E43, pp. 117-126, 1992.

[5] J. Sievert, "Studies of measurement of two-dimensional magnetic phenomena in electrical sheet steel" at PTB. 1st Int. Workshop on Magnetic Properties of Electrical Sheet Steel under Two-Dimensional Excitation. Proceedings of the 93th PTB-Seminar (ed.J.Sievert). PTB-E43 Braunschweig, April 1992, page 102 (ISBN 3-89429-170-2).

[6] J. Sievert, H. Ahlers, M. Enokizono, S. Kauke, L. Rahf, J. Xu, "The measurement of rotational power loss in electrical sheet steel using a vertical yoke system", J.Magn.Magn.Mater. Vol.112, pp. 91-94, 1992.

[7] M. Enokizono, J. D. Sievert, "Magnetic field and loss analysis in an apparatus for the determination of rotational loss", Physica Scripta,Vol.39, pp. 356-359, 1989. 


\section{附録}

従来のヒステリシスループは磁束密度波形並びに 磁界強度波形が一次元的に測定されるので，それらの 二つの波形から構成されるリサージュ図形がヒステリ シスループとなる。これをべクトル磁気特性の視点か らみると, 空間的位相差角 $\theta_{\mathrm{BH}}=0^{\circ}$ である。この場合 の表記は従来法を踏襲し, $H=H_{\mathrm{x}}, H_{\mathrm{y}}=0, B=B_{\mathrm{x}}, B_{\mathrm{y}}=0$, $\theta_{\mathrm{B}}=0^{\circ}$ で表すことになる。

しかしながら，任意方向の磁気特性や回転磁束下の 磁気特性はベクトル関係で表されねばならず，ベクト ル H, B 間の位相角を $\theta_{\mathrm{BH}}$ とする。通常のヒステリシス ループはリサージュ図形で表されたので，同方向成分 の $B_{\mathrm{x}}-H_{\mathrm{x}}, B_{\mathrm{y}}-H_{\mathrm{y}}$ の二つヒステリシスループで表すこ とができるが， $\theta_{\mathrm{BH}}$ の特性が隠れてしまい，特性全体を とらえきれない。本論では，従来の $\mathrm{B}=|\mathbf{B}|$ と $\mathrm{H}=|\mathbf{H}|$ の 関係を $\alpha=0$ の場合と考えて統一的に交番磁束条件は 回転磁束条件の一部と考えてヒステリシスループの表 記方法を提案した。また, 工学的に重要な磁気損失 (鉄 損）に着目すると，磁気損失は次式(1)で表される。

$$
W=\frac{1}{\rho T} \int\left(\mathbf{H}\left[\frac{\partial \mathbf{B}}{\partial t}\right) d t=\frac{1}{\rho T} \int\left(H_{x} \frac{\partial B_{x}}{\partial t}+H_{y} \frac{\partial B_{y}}{\partial t}\right) d t\right.
$$

他方, ベクトル $|\mathbf{B}|,|\mathbf{H}|$ と位相角 $\theta_{\mathrm{BH}}$ を使って表すと， 式(2)となる。

$$
\begin{aligned}
& W=\frac{1}{\rho T} \int\left(\mathbf{H} \frac{\partial \mathbf{B}}{\partial t}\right) d t \\
& =\frac{1}{\rho T} \int|\mathbf{H}|\left|\frac{\partial \mathbf{B}}{\partial t}\right| \cos \theta_{B H} d t+\frac{1}{\rho T} \int \omega_{B}|\mathbf{H}||\mathbf{B}| \sin \theta_{B H} d t
\end{aligned}
$$

ベクトル関係において，各磁気量は

$$
|\mathbf{H}|=\sqrt{H_{x}^{2}+H_{y}^{2}},|\mathbf{B}|=\sqrt{B_{x}^{2}+B_{y}^{2}}
$$

ベクトル関係をヒステリシスループとして表すため, 波形処理して得られた值を

$$
\pm|\mathbf{H}|, \pm|\mathbf{B}|
$$

の表記によってベクトル量と区別し，波形処理によっ て得られる 3 次元的リサージュ図形の 3 象限を, $-|\mathbf{B}|$, 一|H|で表すことにした。これは B が楕円軌跡を描くと して， $|\mathbf{B}|$ は短軸方向で最小值 $|\mathbf{B}|_{\min }$ をとる。 $\pm \mathbf{B} \mid$ とは $|\mathbf{B}|_{\text {min }}$ を境にして $|\mathbf{B}|-|\mathbf{B}|_{\text {min }}$ の值を折り返したものと考えら れるが，後述の波形に示すように $\theta_{\mathrm{BH}}$ の非線形性により単純な 絶対值の折り返しは難しい。
Waveform of $\pm|\mathbf{B}|, \pm|\mathbf{H}|, \theta_{B H}$ Characteristic
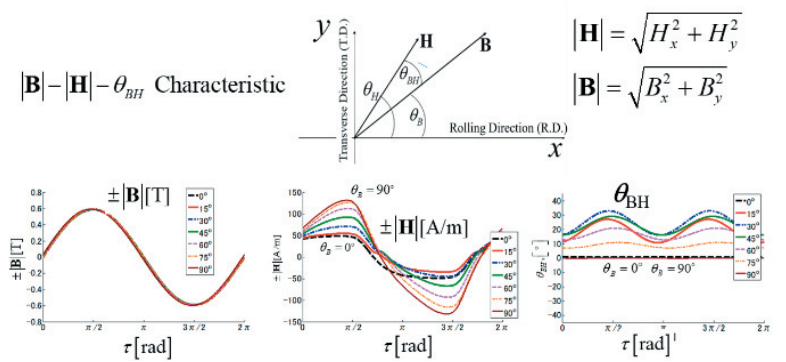

Fig. A Each waveform of arbitrary direction under alternating flux conditions $(\alpha=0)$ of non-oriented electrical steel sheet.



Fig. B Each waveform of arbitrary direction under rotational flux conditions $(\alpha=0.2)$.

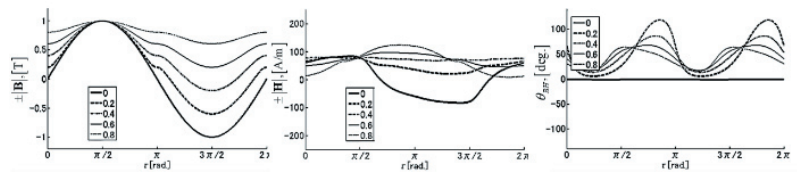

Fig. C Each waveform of rolling direction $\theta_{\mathrm{B}}=0^{\circ}$ under rotational flux conditions $(\alpha=0 \sim 0.08)$.



Fig. D Each waveform of transverse direction $\theta_{\mathrm{B}}=90^{\circ}$ under rotational flux conditions $(\alpha=0 \sim 0.08)$.

Fig. A は交番磁束条件下 $(\alpha=0)$ の任意方向の $\mathbf{B}$ ヘ クトルと $\mathbf{H}$ ベクトルの関係を波形処理した士 $|\mathbf{B}|$ と土 $|\mathbf{H}|$ 及び $\theta_{\mathrm{BH}}$ の各波形を示している。Fig. B は $\alpha=0.2$ の 楕円磁束下の波形では, 正負の非対称性が現れる。Fig. C 及び Fig. D は圧延方向並びに圧延直角方向について, 回転磁束条件の軸比 $\alpha$ を 0 から 0.8 までの変化による 各波形の変化を示す。 $\alpha$ の増加に伴い上下非対称性が 増し，偏磁現象を示す。

以上の 4 種類の波形から士 $|\mathbf{B}|- \pm|\mathbf{H}|-\theta_{\mathrm{BH}}$ の関係 として三次元リサージュ図形をベクトルヒステリシス ループとした。 